Article

\title{
Assessing Customer Preferences for Shopping Centers: Effects of Functional and Communication Factors
}

\author{
Miglè Černikovaitè ${ }^{1, *}$, Žaneta Karazijiené ${ }^{2}$, Lina Bivainienè ${ }^{3}$ and Valdas Dambrava ${ }^{3}$ \\ 1 Department of Communication, Faculty of Human and Social Studies, Mykolas Romeris University, \\ 08303 Vilnius, Lithuania \\ 2 Department of Economics Engineering, Faculty of Business Management, \\ Vilnius Gediminas Technical University, 10223 Vilnius, Lithuania; zaneta.karazijiene@vgtu.lt \\ 3 Department of Advertising and Communication, Faculty of Business Management, \\ Vilniaus Kolegija/ University of Applied Sciences 08303 Vilnius, Lithuania; L.Bivainiene@vvf.viko.lt (L.B.); \\ dvaldas@yahoo.com (V.D.) \\ * Correspondence: miglec@mruni.eu
}

\section{check for}

updates

Citation: Černikovaitè, M.; Karazijienė, Ž.; Bivainienè, L.;

Dambrava, V. Assessing Customer Preferences for Shopping Centers:

Effects of Functional and

Communication Factors.

Sustainability 2021, 13, 3254.

https://doi.org/10.3390/

su13063254

Academic Editor:

Evangelos Grigoroudis

Received: 26 January 2021

Accepted: 10 March 2021

Published: 16 March 2021

Publisher's Note: MDPI stays neutral with regard to jurisdictional claims in published maps and institutional affiliations.

Copyright: (c) 2021 by the authors. Licensee MDPI, Basel, Switzerland. This article is an open access article distributed under the terms and conditions of the Creative Commons Attribution (CC BY) license (https:/ / creativecommons.org/licenses/by/ $4.0 /)$.

\begin{abstract}
Retail companies operating in Lithuania are very important for the national economy. Domestic consumption has remained one of the most important drivers of Lithuania's economic development. The objective of this article is to investigate the customer preferences and to identify selected factors of shopping centers in Vilnius, Lithuania. The study of Vilnius shopping centers is based on a complex model that integrates the following factors: shopping center goods and services, customer service, image factors, physical factors, situational factors and demographic characteristics of target consumers. Expert interviews aimed to determine the customer preference factors by perception of professional experts in relation to the phenomenon under study. The consumer survey questionnaire focuses on all the identified factors that determine the choice of a shopping center. This article identifies theoretical factors for the selection of retail shopping centers, reviews the market trends and peculiarities of Vilnius shopping centers, evaluates the factors for the selection and assess functional, emotional and communicational consumer preferences for the choice of Vilnius shopping centers.
\end{abstract}

Keywords: retail companies; shopping centers; attraction factors; functional; communication and emotional factors; customer preferences

\section{Introduction}

Retail companies are operating in a highly competitive environment. In order to attract new and retain existing customers, retailers should constantly analyze customer choice and preferences. Shopping centers, by providing space and infrastructure for efficient consumer communication with goods and services, can act as a multiplier for tenant's sales revenue by pre-planning and implementing tenant choices so that they complement each other, increase customer flow and drive sales. Retail companies have showed stable growth in recent years. However, there are many challenges arising for retail companies, especially shopping centers, related to the rapid growth of e-commence [1-3]. This sees an increase in logistic properties and a decline in demand for retail properties such as shopping centers [4]. Understandably, the business environment with COVID-19 is changing, so supermarkets will have to offer added value to customers and will change, so sustainability and environmental aspects can become a shopping center exclusivity, thus attracting more customer flows in the future.

He et al. (2021) [5] discussed the importance of real-time consumer information in driving sustainable property development and the importance of innovation to encourage sustainable property development, respectively. Newell and Lee (2012) [4] and Pham and Kim (2019) [6] also showed that property investors and construction firms, including shopping centers, are taking an increased dimension of environment, social and governance. 
There has been little research on the theoretical selected factors for a shopping center. The concept of the shopping center as a "third place" was proposed by Oldenburg (1989) [7], Ritzer and Ryan (2011) [8] raised the idea of "cathedrals of consumption" and examined the factors of their success, while Reikli (2012) [9] examined the key factors of the success of shopping centers. Phelan (2017) [10] explored the importance of the center to both the local community and local government. Other authors have further examined retailspecific factors [9-17]. Reikli (2012) [9] also indirectly considered the affected consumers, but did not directly examine their provisions on the choice of the type of traded object. In Lithuania, there is little research on the evaluation of shopping center factors, but the development of retail trade companies is being studied a lot by authors: Žitkiene and Sekliuckienè (2003) [18], Vengrauskas and Rudienè (2011) [19], Gudonavičienè and Alijošienè, (2013) [20], Sekliuckiene and Langviniene (2011) [21].

The aim of the research is to evaluate the customer preferences and selected factors of large shopping centers in Vilnius. The object of this article is to determine the selected factors of large shopping centers. Vilnius was chosen as it has the highest concentration of shopping centers in Lithuania.

The outline of this article is as follows: first authors analyze the theoretical factors for the selection of shopping centers and their models. Secondly, authors provide a justification for the 58 chosen research methods. Finally, using qualitative and quantitative research methods, authors assess the selected factors of consumer preferences of large shopping centers in the capital of Lithuania.

\section{Literature Review}

By analyzing the definitions of shopping centers, the lack of a common understanding of shopping centers in the scientific literature can be observed. Authors admit that the shopping center can be defined as a specific retail location with a large parking lot. According to the Reikli (2012) [9], a shopping center is defined as a planned and developed group of retail and other commercial establishments, managed as a single property, with owned car parking spaces [22]. As stated by Peiser and Hamilton (2012) [15], a shopping center is a group of architecturally unified commercial establishments built on a plot that is planned, developed, owned and operated as a functional element depending on its location, size, type of shops and service area [14]. Another definition states that it is a planned retail activity and a form of concentrating service objects on a single plot [9]. In summary, the researchers' opinions have broadened the definition of a shopping center and describe the shopping center as a planned, built and uniformly managed commercial building with a leasable area of at least $5000 \mathrm{~m}^{2}$, with at least 10 independent shops (tenants) and where no more than $70 \%$ of the leased area is tenanted [20].

Researchers have conceptualized the functional attributes of a trade object, such as assortment, premises, shops, shopping center atmosphere, shopping center service, reputation, location and parking, promotions and after-sales service [23]. Subsequent research has revealed that the choice of shopping centers is also influenced by the image and identity being created [9], the assortment of stores and goods, emotional experience [24] and the perception of sales performance and quality [25]. According to Rao (2019) [26] a shopping center (1) operates economically and (2) influences the production of urban public life [26].

Other authors $[3,27,28]$ exclude that shopping centers represent a large fraction of global carbon emissions and energy consumption and are faced with sustainability problems. In addition, shopping centers affect local communities in several ways [28]: designated parking spaces and charging stations for electric vehicles and electric bicycles encourage environmentally-friendly modes of transportation [3]; they can also lead to energy- and water-efficient solutions using fossil fuel-free resources [29]. Solar panels on the roof produce electricity and provide shade, which also reduces the need for cooling during summer [30]; waste management and maintenance is also important [27]. Understandably, the business environment in the context of COVID-19 is changing, so 
supermarkets will have to offer added value to customers and will change, so sustainability and environmental aspects can become a shopping center exclusivity, thus attracting more customer flows in the future.

The authors make many different suggestions on how to classify shopping centers. Pantano and Timmermans (2011) [31] analyzed the classification of shopping centers and found that the most popular factors for classifying shopping centers are: size [32], functions [12], ownership and agreements with tenants [12], store supply and destination [12], tenant mix and orientation by product [33], location and service area [12,26,31].

In contrast to Reikli (2012) [9], Dunne, Lusch, and Griffith (2001) [34] performed the classification of shopping centers by type and concept. The International Council of Shopping centers [32] divides Europa shopping centers by type, concept and size (leased area) as well as traditional centers and specialized centers.

The dynamics of the shopping center activity, changes in the competitive environment and assortment formation are explained by the retail life cycle [9,35] retail gravity [33,34] and business cycle $[9,36,37]$ theories. In summary, these theories based on the dynamics of the supermarket explain the stages of the life cycle of the supermarket, how to attract customers, and that the supermarket cannot generate more purchasing power than is present in the service area but may affect the redistribution of consumption costs.

Shopping center selection decisions can be controlled, regulated and changed. According to McCarthy and Perreault (2005) [38], the following rational factors are important when choosing shopping centers: convenient location and parking, variety of offerings, quality of products, support from service staff, reputation of the shopping center, value-added services. In addition to the mentioned factors, Varley and Rafiq (2004) [39] name other factors for choosing shopping centers: attractive prices, really useful exchange/transaction, higher quality additional services, more convenient form of purchase, pleasant and suitable atmosphere and more suitable assortment.

According to Thang and Tan (2003) [23], it is still not clear why shoppers choose one or another shopping center. In their view, the more similar a shopping center is in terms of their consumer buying behavioral profile and demographics, the more often they will visit and be loyal.

Consumers evaluate a variety of alternatives when deciding on a shopping choice. Researchers also stress the importance of consumer satisfaction in the purchasing process. The purpose of the shopping center is to meet the needs of consumers and sometimes even exceed their expectations. According to Dunne, Lusch and Griffith (2001) [34] most buyers value such factors as the shopping center brand, goods, prices and convenience. In addition, Karatepe (2011) [40] emphasizes that service quality is a prerequisite for customer satisfaction.

Another classification of shopping centers is provided by the authors Blackwell, Engel and Miniard (2001) [41]: shopping center location (convenient access and parking), shopping center atmosphere, assortment formation, customer service, pricing solutions, leisure areas and entertainment, advertising, communication and the organization of spectacles. The factors for selecting a center consist of a multifactorial model containing tangible factors such as the location of the center, the number and quality of stores, the layout of the center, and the image of less tangible features such as the atmosphere of the center [41].

Reikli (2012) [9] distinguished three main characteristics of a shopping center brand, which include: (1) assortment (product quality, variety of stores, product range, sales promotion, special events); (2) infrastructure (location of the shopping center, parking lot, quiet recreation areas); (3) market situation (general price level, staff, etc.). A study by Thang and Tan (2003) [23] pointed out that customers could quickly identify such a center by asking what the center is remembered for in terms of its exact characteristics, such as favorable prices, location, and accessibility. Gudonavičienè and Alijošienè (2013) [20] distinguished three functional attributes of shopping centers: atmosphere, parking lot and communication. 
The choice of a shopping center is not only determined by functional attributes. According to Reikli (2012) [9], the choice of a center is more than a summary of its factors, including extraneous elements, emotional content, and actual material. The attractiveness of a shopping center and its functional attributes are inseparable. Often, customers make decisions about the choice of a center based on its image characteristics and image [21]. In branding theories, the term brand image often creates the distinctive character of many products in the mind of the consumer. Nickson, Warhurst and Dutton (2005) [14] demonstrated that brand image techniques can be effectively applied in shopping centers to help increase customer satisfaction and shopping center demand. The more attractive the positive attributes of the center image, the more likely it is that shoppers who visit it will make a purchase. In addition, it should be noted, that retail companies should attempt to enhance their shoppers' experience as a key strategy to attract them to visit a shopping center as many shoppers can do their daily shopping online.

Based on the above material, it is possible to create a shopping center selection model, where the criteria are divided into six groups: goods and services, customer service, physical factors, situational factors, social and demographic factors and other influencing factors. This model (see Table 1) focuses on the study of supermarkets but can also be applied to the study of other types of retail stores.

In summary, in order to evaluate the selected factors of large Vilnius shopping centers, a study is conducted, which examines the following factors: shopping center goods and services, customer service, image factors, physical factors, situational factors and demographic characteristics of target consumers. Through quantitative research methods [10], this research will determine the key factors that determine the choice of a shopping center. Criteria are listed in Table 1.

Table 1. The main factors of selection shopping center.

\begin{tabular}{|c|c|c|c|c|c|}
\hline $\begin{array}{l}\text { Products and } \\
\text { Services }\end{array}$ & Customer Service & Impact Factors & Functional Factors & $\begin{array}{c}\text { Social- } \\
\text { Communication } \\
\text { Factors }\end{array}$ & $\begin{array}{c}\text { Social- } \\
\text { Demographic } \\
\text { Factors }\end{array}$ \\
\hline $\begin{array}{c}\text { Assortment } \\
{[9,33,37,39,41,42]}\end{array}$ & $\begin{array}{c}\text { Quality }[9,20,31,33, \\
38,41,43]\end{array}$ & $\begin{array}{l}\text { Shopping center } \\
\text { image }[14,15,20,41]\end{array}$ & $\begin{array}{c}\text { Location } \\
{[9,12,23,26,31,38]}\end{array}$ & Working hours [42] & Age \\
\hline $\begin{array}{c}\text { Quality of goods } \\
{[33,38,39,43]}\end{array}$ & $\begin{array}{c}\text { Speed } \\
{[9,20,38,41,43]}\end{array}$ & $\begin{array}{c}\text { Public opinion } \\
{[14,20,41]}\end{array}$ & Size $[9,20,32]$ & $\begin{array}{l}\text { Advertising } \\
{[38,41,43]}\end{array}$ & Gender \\
\hline $\begin{array}{c}\text { Price level } \\
{[9,23,38,41,43]}\end{array}$ & $\begin{array}{c}\text { Number of } \\
\text { consultations } \\
{[20,43]}\end{array}$ & $\begin{array}{c}\text { Media opinion } \\
{[14,41]}\end{array}$ & $\begin{array}{c}\text { Atmosphere } \\
{[9,20,39]}\end{array}$ & $\begin{array}{c}\text { Promotion and } \\
\text { sale }[38,41,43]\end{array}$ & Occupation \\
\hline \multirow[t]{3}{*}{$\begin{array}{c}\text { Additional service } \\
{[12,26,31,38,39,41} \\
43]\end{array}$} & & & $\begin{array}{l}\text { Cleanliness and } \\
\text { hygiene }[9,20,39]\end{array}$ & $\begin{array}{c}\text { Loyalty program } \\
{[38,41,43]}\end{array}$ & Income \\
\hline & & & $\begin{array}{c}\text { External } \\
\text { environment } \\
{[9,20,39]}\end{array}$ & $\begin{array}{c}\text { Emotional factors } \\
{[26]}\end{array}$ & Transport \\
\hline & & & $\begin{array}{l}\text { Access and } \\
\text { parking lot } \\
{[9,20,23,38]}\end{array}$ & & \\
\hline
\end{tabular}

Source: developed by authors based on the literature review.

The research framework for this study is submitted below in Figure 1. 


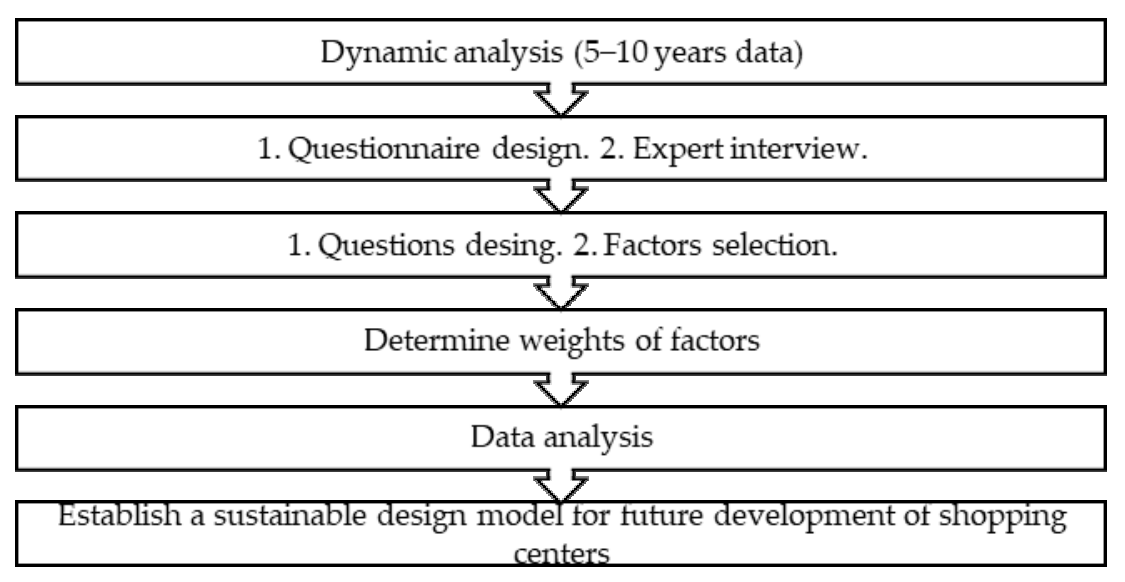

Figure 1. Research framework for the study.

Therefore, the objectives of this study are to:

1. Discuss selections factors (functional and socio-communication) of customer preference for shopping centers.

2. Construct a hierarchical framework of establish a sustainable design model of future development of shopping centers.

\section{Materials and Methods}

Dynamic analysis of secondary data, quantitative research of primary data (survey) and qualitative expert interviews were chosen for the research; this is called mixed methods research. Mixed methods may be defined as "research in which the investigator collects and analyses data, integrates the findings and draws inferences using both qualitative and quantitative approaches or methods in a single study" [44]. Research is not restricted by the use of traditional approaches to data collection but is guided by a foundation of enquiry that underlies the research activity [45]. A mixed methods study is one that includes a qualitative and quantitative dimension, but difficulties often arise when the researcher attempts to articulate how the two elements relate to one another [45].

Dynamic analysis (5-10 years data) was conducted in order to find out the main tendencies of shopping center activities in the capital of Lithuania, Vilnius. The advantage of this study is that from the secondary slopes it is possible to define and analyze development trends and dynamics of shopping center development in Lithuania. A period of 5-10 years was chosen for the analysis of secondary data, period and the characteristics and operating dynamics of 5 shopping centers are analyzed.

Consumer surveys ( $n=507)$ and expert interviews helped us to find out whether city residents, regardless of their place of residence, value the choice of shopping center to meet their purchasing needs. This research also identifies the factors that most influence consumers when choosing large shopping centers in Vilnius. A questionnaire was selected for the quantitative customer study and included 23 closed-ended questions (answers provided, multiple choice, and matrices with Likert scales) in which to express their views. Various studies and research papers were analyzed to compile the quantitative research questionnaire.

The sample of 507 respondents were selected for the quantitative survey by random non-probability sampling with $4.3 \%$ margin error. Target group: $16-59$ years' residents of Vilnius city and district who at least once in 3 months visits at least one of the following shopping centers: Ozas, Akropolis, and Panorama. A quantitative study was conducted in 2019 May by interviewing respondents both locally and remotely in Vilnius. The demographic and socio-economic information of respondents is presented in the Table 2. 
Table 2. Demographic information on valid questionnaire respondents.

\begin{tabular}{|c|c|c|c|}
\hline Attribute & Category & Total Number of People & Percentage \\
\hline \multirow[b]{2}{*}{ Gender } & Male & 228 & 45 \\
\hline & Female & 279 & 55 \\
\hline \multirow{5}{*}{ Age } & $16-19$ & 15 & 3 \\
\hline & $20-29$ & 167 & 33 \\
\hline & $30-39$ & 167 & 33 \\
\hline & $40-49$ & 105 & 21 \\
\hline & $50-59$ & 53 & 10 \\
\hline \multirow{8}{*}{ Occupation } & Business owner & 25 & 5 \\
\hline & Business manager & 20 & 4 \\
\hline & Specialist & 264 & 52 \\
\hline & Worker & 60 & 12 \\
\hline & Student & 101 & 20 \\
\hline & Housewife & 30 & 6 \\
\hline & Pensioner & 0 & 0 \\
\hline & Unemployed & 7 & 1 \\
\hline \multirow{8}{*}{ Monthly income } & No data & 88 & 17 \\
\hline & Up to 200 EUR & 30 & 6 \\
\hline & 201-400 EUR & 101 & 20 \\
\hline & 401-600 EUR & 127 & 25 \\
\hline & 601-800 EUR & 86 & 17 \\
\hline & 801-1000 EUR & 30 & 6 \\
\hline & 1001-1200 EUR & 25 & 5 \\
\hline & More than 1200 EUR & 20 & 4 \\
\hline \multirow{2}{*}{ Owns car } & Yes & 410 & 81 \\
\hline & No & 97 & 19 \\
\hline
\end{tabular}

Source: authors' creation.

Out of 507 of the respondents to the survey, $65 \%$ were women and $35 \%$ were men. The majority of respondents represented the two largest age groups 20-29 years and 30-39 years (33\% each), as well as $21 \%$ of respondents were men and women aged $40-49$. Most of them $(91 \%)$, who have a car $(81 \%)$, specialists and employees $(51 \%)$, receive an average of 401-600 EUR income.

Most of them are Acropolis customers. Two-thirds of the target audience visits it monthly or more often; 55\% visit Ozas and 43\% visit Panorama. Visitors to the Ozas are a little younger than the Acropolis or the Panorama, with more of them having a car. Acropolis is the most versatile of its customers are of different age groups, there are no significant differences between other socio-demographic groups. Visitors to Panorama are from a slightly higher level of society, more often from higher positions with higher incomes.

Expert interviews were selected which use pre-prepared questions that are known to the interviewee in advance. The aim of the research is to determine the opinion, attitude and perception of professional experts in relation to the researched phenomenon.

A total of 6 experts with professional experience in the field of commercial real estate management, advertising and marketing, who work or have worked with the shopping centers Ozas, Akropolis, Europa, Panorama and CUP, were selected for the qualitative study qualitative survey analysis is performed and results are presented. During the study, six shopping center experts were interviewed, their data are presented in Table 3. 
Table 3. List of qualitative research experts and justification of their competence.

\begin{tabular}{|c|c|c|}
\hline EXPERTS & POSITION & $\begin{array}{c}\text { Experience Working with Shopping } \\
\text { Centers }\end{array}$ \\
\hline Expert No.1 & $\begin{array}{l}\text { Shopping center developer } \\
\text { consultant, rental manager }\end{array}$ & $\begin{array}{c}6 \text { years worked as the rental manager of UAB } \\
\text { ECE Project management (Ozas), } 5 \text { years as } \\
\text { UAB Baltic Shopping Centers Rental } \\
\text { manager (Mega, Banginis), }\end{array}$ \\
\hline Expert No.2 & $\begin{array}{l}\text { General Director of UAB } \\
\text { Akropolis group }\end{array}$ & $\begin{array}{c}2.5 \text { years was the General Director of UAB } \\
\text { Akropolis group, "Akropolis" Development } \\
\text { manager in Riga in } 2019\end{array}$ \\
\hline Expert No.3 & Director of GO9 & 6.5 years as Director of GO9; \\
\hline Expert No.4 & $\begin{array}{c}\text { Director of UAB Prosperitas } \\
\text { Baltica }\end{array}$ & 15.5 years as Director of CUP \\
\hline Expert No.5 & Marketing Manager specialist, & $\begin{array}{c}6 \text { years worked for shopping centers } \\
\text { "Akropolis", } 8 \text { years. “Ozas", } 1.5 \text { years UAB } \\
\text { Westerwijk valdymas }\end{array}$ \\
\hline Expert No.6 & $\begin{array}{l}\text { Real estate development } \\
\text { specialist, consultant }\end{array}$ & $\begin{array}{l}7 \text { years as UAB Newsec asset management } \\
\text { group manager, } 4 \text { years was the Head of the } \\
\text { rental department of UAB Resolution }\end{array}$ \\
\hline
\end{tabular}
Source: authors' creation.

The selection of shopping center experts (see Table 3) was made according to the following factors: (1) more than five years of continuous work experience with shopping centers in Lithuania; (2) the nature of the work related to strategic management or marketing communications planning and strategy development; (3) Experience in effective and ineffective management solutions and marketing communication campaigns. Participants participated in the survey voluntarily and free of charge. A qualitative study was conducted during the period December 1-10 2019 in Vilnius, both online and by conducting live interviews. The participants of the research were acquainted with the research, its goals and problems.

\section{Results}

After summarizing the evaluation factors of shopping centers distinguished by researchers in the theoretical part of the article, Vilnius shopping centers were classified according to the data published by secondary sources and the shopping centers themselves (see Table 4).

Table 4. Classification of Vilnius shopping centers according to different authors.

\begin{tabular}{|c|c|c|c|c|c|c|}
\hline $\begin{array}{c}\text { Name of Shopping } \\
\text { Center in }\end{array}$ & Trading Area, $\mathrm{m}^{2}$ & By Type & By Size & By Purpose & $\begin{array}{c}\text { By ICSC } \\
\text { Classification } \\
{[46]}\end{array}$ & $\begin{array}{c}\text { By Levy, Witz } \\
\text { and Grewal } \\
(2019)[42]\end{array}$ \\
\hline Akropolis & 98.000 & $\begin{array}{c}\text { Traditional } \\
\text { shopping center }\end{array}$ & Extra large & General purpose & Superregional & Shopping center \\
\hline Ozas & 62.000 & $\begin{array}{c}\text { Traditional } \\
\text { shopping center }\end{array}$ & Large & General purpose & Regional & Shopping center \\
\hline Panorama & 56.000 & $\begin{array}{c}\text { Traditional } \\
\text { shopping center }\end{array}$ & Large & General purpose & Regional & Shopping center \\
\hline CUP & 26.000 & $\begin{array}{c}\text { Traditional } \\
\text { shopping center }\end{array}$ & Average & General purpose & District & $\begin{array}{l}\text { Neighborhood/ } \\
\text { Community } \\
\text { Center }\end{array}$ \\
\hline Outlet Parkas & 19.500 & Specialized & Average & Specialized & Outlets & Outlet center \\
\hline Europa & 17.500 & Specialized & Small center & Specialized & District & Fashion Center \\
\hline Ogmios centras & N.D. & Specialized & Shopping park & Specialized & District & Omni Centre \\
\hline
\end{tabular}


Table 4. Cont.

\begin{tabular}{|c|c|c|c|c|c|c|}
\hline $\begin{array}{c}\text { Name of } \\
\text { Shopping Center } \\
\text { in }\end{array}$ & $\begin{array}{l}\text { Trading Area, } \\
\mathbf{m}^{2}\end{array}$ & By Type & By Size & By Purpose & $\begin{array}{c}\text { By ICSC } \\
\text { Classification } \\
{[46]}\end{array}$ & $\begin{array}{l}\text { By Levy, Witz } \\
\text { and Grewal } \\
(2019)[42]\end{array}$ \\
\hline Nordika & 35.000 & $\begin{array}{c}\text { Traditional } \\
\text { shopping center }\end{array}$ & Average & $\begin{array}{l}\text { General } \\
\text { purpose }\end{array}$ & District & $\begin{array}{c}\text { Neighborhood/ } \\
\text { Community } \\
\text { Center }\end{array}$ \\
\hline Big & 28.000 & $\begin{array}{c}\text { Traditional } \\
\text { shopping center }\end{array}$ & Average & $\begin{array}{l}\text { General } \\
\text { purpose }\end{array}$ & District & $\begin{array}{c}\text { Neighborhood/ } \\
\text { Community } \\
\text { Center }\end{array}$ \\
\hline Mandarinas & 7.800 & $\begin{array}{c}\text { Traditional } \\
\text { shopping center }\end{array}$ & Small & $\begin{array}{l}\text { General } \\
\text { purpose }\end{array}$ & District & $\begin{array}{c}\text { Neighborhood/ } \\
\text { Community } \\
\text { Center }\end{array}$ \\
\hline Mada & 27.800 & $\begin{array}{c}\text { Traditional } \\
\text { shopping center }\end{array}$ & Small & $\begin{array}{l}\text { General } \\
\text { purpose }\end{array}$ & District & $\begin{array}{c}\text { Neighborhood/ } \\
\text { Community } \\
\text { Center }\end{array}$ \\
\hline
\end{tabular}

Source: developed by the authors on the basis of ICSC [46], Levy, Witz and Grewal (2019) [42].

Table 4 lists the major supermarkets and describes them according to various criteria. The 3 most important selection criteria for the study are: (1) by type (select traditional shopping center according to this criterion); (2) by purpose (select only with the attribute general purpose) (3) by By Levy, Witz and Grewal (2019) [42] (select only shopping centers). The following supermarkets were selected for further research according to these 3 main criteria: Akropolis, Ozas, Panorama, CUP

The classification of Vilnius shopping centers according to different authors presented in Table 5 shows that there are no uniform qualification factors according to which shopping centers could be divided. From Table 5 we can see that the largest shopping centers in Vilnius can be considered: "Acropolis", "Ozas", "Panorama", "Europa", "CUP”.

When analyzing shopping centers, it is very important to assess the European context. The saturation ratio is used for this. As noted by Delic and Knezevic (2014) [36], the area of shopping centers can only grow to a certain level of market saturation. Lithuania exceeds the EU average in terms of shopping center density [46]. It is estimated that we have $400.1 \mathrm{~m}^{2}$ of modern shopping center area per thousand inhabitants. The density in Lithuania is exceeded by Austria, Great Britain, Ireland, Estonia and the Scandinavian countries (see Figure 2).

Assessing the retail sector of the Republic of Lithuania, a significant increase in the turnover of retail trade enterprises has been observed in recent years. In January to September 2019, the retail trade turnover in non-food products at constant prices was $9.3 \%$ higher than in the corresponding period of 2018. However, for 2020-2021, growth may be significantly slower due to slower economic growth, wage growth and declining household spending due to COVID-19. However, despite the crisis, shopping centers are reorganizing and aiming to further improve the visitor experience. Owners and managers of real estate developers and shopping centers want shopping centers to become part of the city's infrastructure, strengthening the need for communication, sociality, city life or even art and culture. Shopping centers located in the city center focus not only on fashion, service and restaurant centers, but also involve business, for example, opening up co-working spaces. A larger project can be expected to open in Vilnius in 2020. When the Vilnius Outlet shopping center is built next to the Western Bypass, this would supplement the capital's market with about 35,000 sq.m of retail space. Such a larger project would be implemented in Vilnius after a break of 4.5 years [47]. 


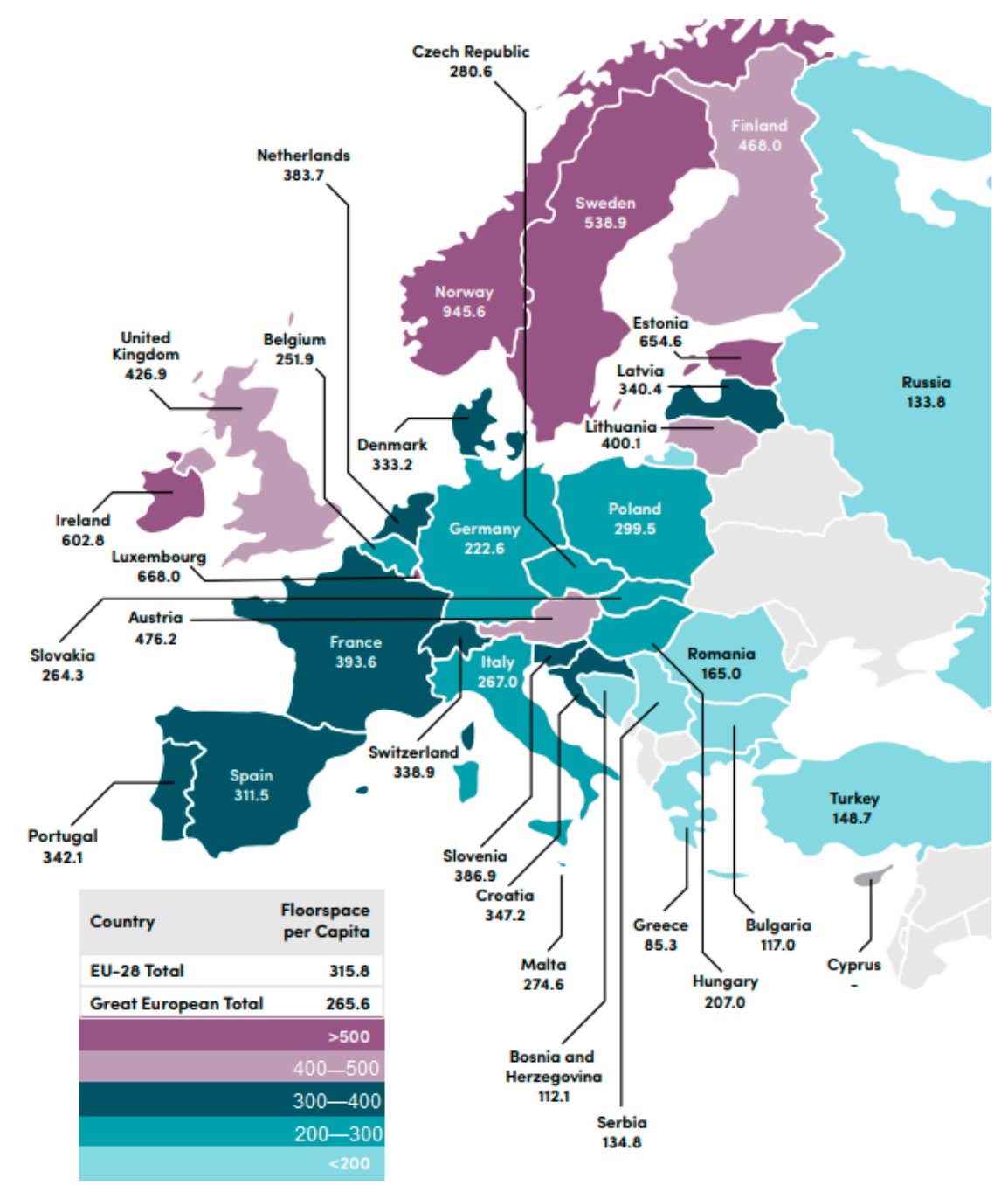

Figure 2. Density of shopping centers (GLA sq. m/1000 population) [27].

Another new trend in the Baltics is that more and more shopping centers are concentrated in the hands of financial investors, as developers who have built shopping centers transfer them to investment funds (both large international and local capital funds). Only during 2017-2018 in the Baltic States, 11 larger shopping centers were transferred to investors, of which 5 transactions took place in Lithuania [47]. The largest in terms of tenant turnover in 2018 is the Acropolis of Vilnius. Naturally, the influence of this center on the retail trade in Vilnius is much greater than in any other center, in any other city. In Lithuania, Vilnius Ozas and Panorama stand out with their marketing actions, introduction of new store concepts, and they are approaching the leaders [48].

Respondents were asked about spontaneous associations that arise after naming one of the large shopping centers in Vilnius (see Table 5). 
Table 5. Spontaneous associations of respondents about major shopping centers in Vilnius.

\begin{tabular}{|c|c|c|c|c|c|}
\hline \multicolumn{2}{|c|}{ AKROPOLIS } & \multicolumn{2}{|l|}{ PANORAMA } & \multicolumn{2}{|l|}{ OZAS } \\
\hline Top Mentions & $\%$ & Top Mentions & $\%$ & Top Mentions & $\%$ \\
\hline $\begin{array}{c}\text { Lots of } \\
\text { shops/large } \\
\text { selection }\end{array}$ & 22 & $\begin{array}{c}\text { Convenient } \\
\text { location/close to } \\
\text { home }\end{array}$ & 8 & Movie Theater & 14 \\
\hline Many people & 19 & Events/exhibitions & 8 & $\begin{array}{c}\text { Lots of } \\
\text { shops/large } \\
\text { selection }\end{array}$ & 10 \\
\hline Movie theater & 10 & $\begin{array}{c}\text { Lots of } \\
\text { shops/large } \\
\text { selection }\end{array}$ & 7 & Grocery Store & 9 \\
\hline $\begin{array}{l}\text { Fun/interesting } \\
\text { activities }\end{array}$ & 9 & $\begin{array}{c}\text { Shopping } \\
\text { center/shops }\end{array}$ & 7 & $\begin{array}{c}\text { Shopping } \\
\text { center/shops }\end{array}$ & 8 \\
\hline Large & 9 & Restaurants/cafes/food & 6 & Spacy & 8 \\
\hline $\begin{array}{c}\text { Shopping } \\
\text { center/shops }\end{array}$ & 9 & Grocery Store & 6 & $\begin{array}{c}\text { For } \\
\text { children/families }\end{array}$ & 7 \\
\hline Ice arena & 8 & $\begin{array}{c}\text { Far/uncomfortable } \\
\text { to come }\end{array}$ & 6 & Restaurants/cafes/food & 5 \\
\hline Grocery Store & 7 & Cozy/nice/tidy & 6 & $\begin{array}{c}\text { Interesting/good } \\
\text { shops }\end{array}$ & 5 \\
\hline $\begin{array}{l}\text { Household } \\
\text { goods store }\end{array}$ & 4 & Convenient & 5 & Events/exhibitions & 4 \\
\hline Noise/hustle & 4 & Information/Television & 5 & Convenient & 4 \\
\hline
\end{tabular}

The main expressed feature of shopping center "AKROPOLIS" is size, abundance, a lot of shops, congested, noisy. There are many shops, goods, people and cars. Among the negative features, it was mentioned that it is an old/obsolete shopping center. Panorama does not have one or more dominant attributes. Its location is more convenient than "Ozas" or "Akropolis", and its advantages are events, exhibitions, fairs. For "OZAS", the center is primarily associated with the shops or entertainment venues there. The most striking link is with the Multikino cinema and with spaces or events for children and families.

Respondents were further asked to evaluate the functional factors of Vilnius shopping centers (evaluation scale: 1 -strongly disagree; 5 -strongly agree). Ozas was found to be seen as a shopping and entertainment center suitable for the whole family (answer average 4.18). Additionally, the advantages of the center are the range of goods and services (3.92), variety (3.93) and good service (3.88). According to the respondents, the advantage of the Acropolis is that one can find everything inside, i.e., it offers a wide range of goods (4.11), suitable for the whole family (4.09). Ease of arrival is rated similarly to Ozas (3.97). The biggest disadvantage of the Acropolis is the price-quality ratio (2.34), food zones (2.56), troublesome environment (2.93), and congestion. Panorama is family-friendly (3.84) and is the center's highest rating. Events are also well appreciated (3.81). The CUP's best-rated factors are the same as those of the Acropolis: family-friendly (4.1), variety of shops (3.9), wide range (3.98) and convenient location (4.32), but it is necessary to note that the rating of this criterion is much higher than that of the Acropolis. The ratings of the Europa shopping center are significantly lower than those of other shopping centers. We found no correlation between income $\left(\chi^{2}(16,507)=22.871, p>0.01\right)$ and age groups $\left(\chi^{2}(16,507)=15.371, p>0.01\right)$ with spontaneous associations of respondents about major shopping centers in Vilnius.

The evaluation of the factors of shopping centers revealed that the highest indicators of Vilnius large shopping centers are in the same categories (see Table 6). 
Table 6. The evaluation factors of large shopping centers in Vilnius, mean, standard deviation and correlation.

\begin{tabular}{|c|c|c|c|c|c|c|c|c|c|}
\hline Dimension & Evaluation Criteria & Mean & SD & Location & Variety & $\begin{array}{l}\text { Wide } \\
\text { Range }\end{array}$ & $\begin{array}{l}\text { Food } \\
\text { Zones }\end{array}$ & $\begin{array}{c}\text { Price- } \\
\text { Quality }\end{array}$ & $\begin{array}{c}\text { Big } \\
\text { Parking }\end{array}$ \\
\hline \multirow{7}{*}{$\begin{array}{l}\text { Functional } \\
\text { Factors }\end{array}$} & $\begin{array}{c}\text { Convenient } \\
\text { location }\end{array}$ & 3.97 & 0.7279 & 1.00 & & & & & \\
\hline & Variety of shops & 3.58 & 0.7761 & 0.002 & 1.00 & & & & \\
\hline & $\begin{array}{l}\text { Wide range of } \\
\text { goods }\end{array}$ & 3.72 & 0.7739 & $0.118^{* *}$ & $-0.314^{* *}$ & 1.00 & & & \\
\hline & Food zones & 2.64 & 0.5674 & 0.051 & $-0.564^{* *}$ & 0.023 & 1.0 & & \\
\hline & Price-quality ratio & 2.74 & 0.9803 & -0.021 & $0.045^{* *}$ & $0.448 *$ & 0.331 & 1.00 & \\
\hline & Big parking lot & 3.64 & 0.8654 & $0.518 *$ & $-0.067^{* *}$ & $0.421 * *$ & -0.342 & -0.045 & 1.00 \\
\hline & & & & $\begin{array}{l}\text { Family } \\
\text { friendly }\end{array}$ & $\begin{array}{l}\text { Working } \\
\text { hours }\end{array}$ & $\begin{array}{l}\text { Customer } \\
\text { service }\end{array}$ & Design & Atmosphere & Events \\
\hline \multirow{7}{*}{ Social factors } & Family friendly & 3.94 & 0.6747 & 1.00 & & & & & \\
\hline & Working hours & 2.86 & 0.6854 & 0.005 & 1.00 & & & & \\
\hline & $\begin{array}{l}\text { Customer service } \\
\text { quality }\end{array}$ & 3.37 & 0.7379 & 0.014 & -0.342 & 1.00 & & & \\
\hline & Atmosphere & 3.21 & 0.7303 & $0.517^{* *}$ & 0.032 & 0.546 & 1.00 & & \\
\hline & $\begin{array}{c}\text { Events quality and } \\
\text { quantity }\end{array}$ & 3.27 & 0.6747 & $0.474^{* *}$ & 0.045 & 0.321 & -0.265 & 1.00 & \\
\hline & $\begin{array}{l}\text { Entertainment } \\
\text { variety }\end{array}$ & 2.99 & 0.8758 & 0.054 * & $0.457^{* *}$ & 0.023 & -0.321 & 0.342 & 1.00 \\
\hline & & & & Advertising & Promotion & Loyalty & Design & & \\
\hline \multirow{4}{*}{$\begin{array}{l}\text { Communication } \\
\text { factors }\end{array}$} & Advertising & 3.45 & 0.8769 & 1.00 & & & & & \\
\hline & Promotion and sale & 4.23 & 0.6423 & $0.558^{* *}$ & 1.00 & & & & \\
\hline & Loyalty program & 3.12 & 0.5734 & $0.320 * *$ & -0.342 & 1.00 & & & \\
\hline & $\begin{array}{l}\text { Internal and } \\
\text { external design }\end{array}$ & 2.99 & 0.7689 & -0.023 * & -0.032 & -0.451 & 1.00 & & \\
\hline
\end{tabular}

Note: $\mathrm{M}=$ mean; $\mathrm{SD}=$ Standard Deviation; ${ }^{* *}$-significant at $p<0.01 ;{ }^{*}$ —significant at $p<0.05$. Source: authors' creation.

This study sought to highlight the advantages and disadvantages of shopping centers. Respondents singled out the main advantages of large Vilnius shopping centers: 1 ) exclusive goods and shops (25\%), cinema (18\%), convenient access (12\%). Most of all, $32 \%$ of respondents said they had no complaints, $14 \%$ missed food stores, while $10 \%$ missed clothing stores and more.

No significant correlations between functional, social and communication factors were observed. There was no correlation between income and functional factors shopping centers in Vilnius $\left(\chi^{2}(16,507)=22.871, p>0.01\right)$. However, we found the variation of price level perception in different age groups $\left(\chi^{2}(16,507)=1296.844, p<0.01\right)$ and identification of respondents with the favorite supermarket in different age groups $\left(\chi^{2}(16,507)=541.649\right.$, $p<0.01)$. Both associations show strong relationships. The difference in price level perception and identification with favorite supermarket between 16-39 and 40-54 age groups in the case of Ozas and Akropolis is the largest.

These findings are in line with suggestions derived from prior studies. Reikli (2010) [9] note that functional factors such as price level perception is one of reasons to choose a shopping center for different age groups. Thang and Tan (2003) [23] point out that customers tend to identify themselves with their favorite supermarket. Gudonavičiene and Alijošienè (2013) [20] distinguished three functional attributes of shopping centers: atmosphere, parking lot and communication that in particular not have impact for different age and income groups.

This study identified that various promotions and sales would encourage shopping center visitors to visit shopping centers more often; the grocery store is also important. Previous questions have shown that there is a sufficient number of events, entertainment, 
various shops, so communication is important for the majority of the population to know about it.

A qualitative study was also conducted to better assess the factors for selecting shopping centers. The generalized spontaneous associations of experts are presented in Table 7.

Table 7. Spontaneous associations of experts about major shopping centers in Vilnius.

\begin{tabular}{ccc}
\hline Shopping Centers & Associations & Statements \\
\hline AKROPOLIS & Large & $\begin{array}{c}\text { Big and old } \\
\text { Fost people and from the } \\
\text { province }\end{array}$ \\
PANORAMA & Gourmet food & $\begin{array}{c}\text { For everyone } \\
\text { Gourmet area, gourmets, more expensive, } \\
\text { good place for lunch }\end{array}$ \\
OZAS & For young people & $\begin{array}{c}\text { Niche fashion; more interesting shops, } \\
\text { aesthetics, fewer people }\end{array}$ \\
\hline CUP & Restaurants & Fast, aggressive, youth, events \\
& Lots of shops & $\begin{array}{c}\text { Restaurants } \\
\text { Lots of "other" open-air shops and } \\
\text { services }\end{array}$ \\
\hline EUROPA & Expensive & Luxury stores and brands \\
\hline
\end{tabular}

Source: authors' creation.

Expert insights differ little from the exclusivity declared by the shopping centers themselves. Summarizing the opinion of experts on this issue, it is obvious that the Acropolis has a refined positioning: first, big, and for everyone. This was assessed by 4 experts out of 6 . The shopping center Ozas does not have a clear positioning but rather has a bit of everything: a shopping center for events, entertainment, family and youth fashion. With the opening of the Gourmet area, Panorama has created the exclusivity of a shopping and a food center. The uniqueness of the CUP is its good location and restaurants. Due to the uniqueness of shopping center "Europa", the experts were not united. For some, it is a luxury brand, for others it is an impure center communicating as urban fashion but acting as a local center. Most experts believe that the uniqueness of large shopping centers is a good location, convenient and spacious parking, refined assortment, well-planned and refined food and recreation areas. Shopping centers have learned to create value through other value components. Akropolis, Panorama and CUP have clear positioning, while the distinctions of Ozas and Europa were less clearly communicated.

The aim was to assess the functional characteristics of each shopping center that could potentially lead to their selection (see Figure 3).

Based on their experience, the experts evaluated the selection indicators of all shopping centers. There is a tendency for "Akropolis" to be rated the best, followed by "Ozas", "Panorama", "CUP" and the worst rated shopping center "Europa". For each center, the experts singled out those functional features that attract people to drive to the centers. 


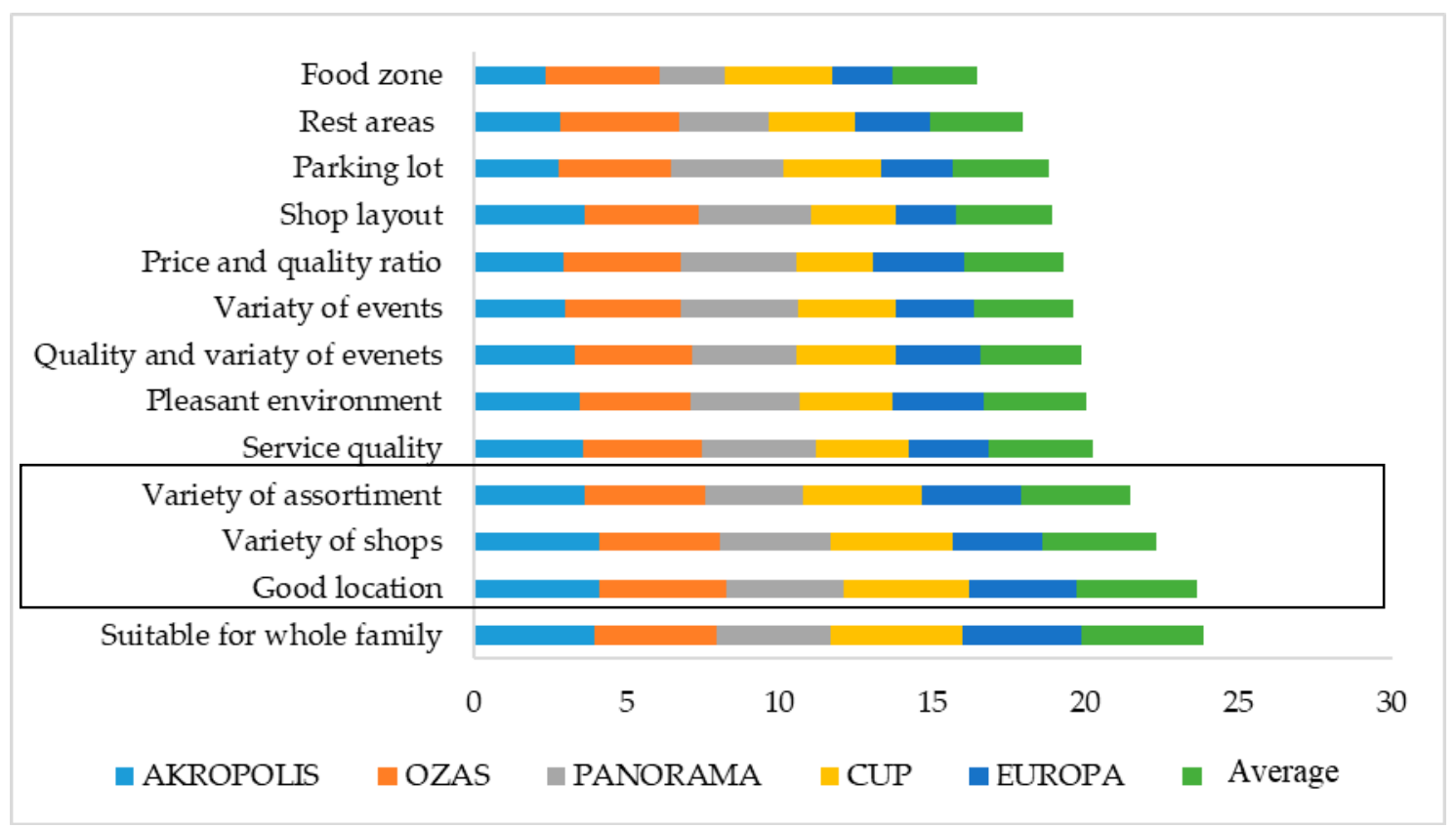

Figure 3. Functional selected factors of shopping centers.

The aim of this study was to assess the problems most often faced by large shopping centers in Vilnius. The experts identified the biggest problems:

1. Limited purchasing power of buyers and their number (three experts).

2. Increasing the flow of customers and attracting new brands to the market (two experts).

3. Internet trade, competition between shopping centers (one expert).

4. Customer engagement or customer loyalty (one expert).

5. Ability to respond more quickly to the latest retail trends such as: food and beverage, sports and wellness, education, community gathering, co-working. These solutions require appropriate buildings, architectural possibilities and large investments (one expert).

The aim was also to determine how to attract more customers to shopping centers in Vilnius. The experts made the following recommendations (see Table 8).

Table 8. How to attract the customers to shopping centers in Vilnius.

\begin{tabular}{|c|c|}
\hline Rational Statements & Emotional Attachment of Customers \\
\hline $\begin{array}{c}<\ldots \text { Good tenant mix (choice of stores), } \\
\text { convenient layout and parking, marketing ... } \\
<\ldots \text { The widest choice of services; comfortable } \\
\text { leisure areas ... }> \\
<\ldots \text { More interesting entertainment, social } \\
\text { projects, events (fashion, educational, } \\
\text { conferences ... > } \\
<\ldots \text { Clearer navigation and positioning, } \\
\text { exclusivity ... > }\end{array}$ & $\begin{array}{c}<\ldots \text { Emotion is the main engine of sales. } \\
\text { Trends in shopping centers show that more } \\
\text { and more often the visitor comes not for } \\
\text { shopping, but for entertainment ... } \\
<\ldots \text { Personalization and customer } \\
\text { engagement through digital solutions }(. . .) \\
\text { where the customer can share ideas, } \\
\text { suggestions, automate purchases, queuing, e.g., } \\
\text { post office, pay for parking ... > } \\
<\ldots \text { Assessing Customer Priorities ... > }\end{array}$ \\
\hline
\end{tabular}

Source: authors' creation.

Deepening the theoretical premise of customer loyalty and exclusivity, experts were asked what can help create shopping center exclusivity when most are very similar. According to experts, large shopping centers in Vilnius can be distinguished by their interior, layout and entertainment. Shopping centers are advised to follow market innovations and integrate new services such as a concert hall. According to experts, shopping centers must become multifunctional objects, they can include a hotel, offices and a concert hall and even residential apartments. 
The last question was asked by experts whether there is a demographic-economic basis for the emergence of new shopping centers in Vilnius. Expert opinions were singled out. Some did not agree with this, others pointed out that new shopping centers are already being built and planned in Vilnius. According to the market saturation theory, a new customer will not be formed, the population of Lithuania is decreasing, and a higher attraction of the population to the surrounding countries is unlikely. Currently, seeing the statistics (in a demographic sense), the increase in shopping centers will affect the reorganization, closure, change of purpose of some shopping centers. The economic situation calls into question the benefits of development. However, considering the availability of free funds in the market and the expectation of lower returns, the new shopping center(s) will definitely be developed.

\section{Discussion}

The results of questionnaire analysis indicated that the main selected factors of shopping centers cover the same categories: convenient location (3.97), suitable for the whole family (3.94), variety of shops (3.58) and a wide range of goods (3.72). The worst rated categories are: food zones (2.64), price-quality ratio (2.74) and variety of entertainment (2.99). This indicated that shopping mall operators value the location and develops the more comfort for time spending with the family.

This study highlighted the advantages and disadvantages of shopping centers. Respondents singled out the main advantages of large Vilnius shopping centers: 1) exclusive goods and shops (25\%), cinema (18\%), convenient access $(12 \%)$. Most of all, $32 \%$ of respondents said they had no complaints, $14 \%$ missed food stores, and $10 \%$ missed clothing stores and more.

The experts identified the biggest problems and highest potential for future developments of the shopping centers: 1 . limited purchasing power of buyers and their number (three experts); 2 . increasing the flow of customers and attracting new brands to the market (two experts); 3. internet trade, competition between shopping centers (one expert); 4. customer engagement or customer loyalty (one expert); 5 . ability to respond more quickly to the latest retail trends such as: food and beverage, sports and wellness, education, community gathering, co-working. These solutions require appropriate buildings, architectural possibilities and large investments (one expert).

\section{Research Limitations and Future Study}

Due to the COVID-19 pandemic and quarantine restrictions, the operation shopping centers in Lithuania has stopped. As a result, the managers of these buildings are already suffering losses and this will continue as long as there are quarantine restrictions. It is difficult to predict what the decline will be, as it will depend on when the quarantine ends.

There is a tendency towards the development of leisure and sports goods traders, who are already looking for premises for rent, to expand faster. Additionally, due to limited opportunities for direct sales, the combination of e-commerce and physical stores will continue to be popular. This synergy, which has emerged as a result of COVID-19, is evolving rapidly. Between the first and second quarantines, a large number of traders have set up platforms and make more use of e-commerce during the second quarantine [37]. The author's recommendation for future research also relates to the need to conduct further research that will evaluate the selected factors of shopping centers changes due to the COVID-19 pandemic and research should be focused not only the largest shopping centers of the capital of Lithuanian, but will cover the whole country.

\section{Conclusions}

In order to identify the theoretical factors for the selection of retail centers, an analysis was performed, on the basis of which the selected factors were divided into six groups: goods and services, services, physical factors, situational factors, social and demographic 
factors and other influencing factors. These factors focus on the study of shopping centers but can also be applied to the study of other types of retail stores.

The analysis of theoretical shopping center material revealed that there is no standard definition of a shopping center. The concept of the shopping center concept is formed in practice and new elements and important attributes have been added over time. After the quantitative research, the selected factors of large Vilnius shopping centers were determined and consumer preferences regarding the choice of large Vilnius shopping centers were clarified. It was found that the shopping centers are associated with specific brands, convenient location, family suitability, variety of shops with pleasant and professional service, cozy, spacious, unoccupied environment and parking lots. Various promotions and sales are also very important in Lithuania.

After a qualitative study, it can be confirmed that the uniqueness of large shopping centers in Vilnius is a good location, a lot of parking space, refined assortment, wellplanned and refined food and recreation areas; these are the qualities that can improve the market position of shopping centers in Vilnius. The qualitative research helped to identify the biggest problems and threats of Vilnius shopping centers: limited purchasing power and number of buyers, increasing the flow of customers and attracting new brands to the market, online trade and competition.

In order to improve the attraction of customers to major shopping centers in Vilnius, it is recommended to create a multifunctional purpose of the shopping center by creating coworking spaces, entertainment and recreation areas, offices, hotels, medical institutions, etc. Shopping centers in Vilnius should focus more on modernity, technology, experience, which can be tested in the shopping center, rather than online. The new generation of consumers who spend a lot of time in shopping centers will want more innovative technological entertainment, events and spaces for self-expression.

Author Contributions: For research articles with several authors, a short paragraph specifying their individual contributions must be provided. M.Č. and Ž.K. developed the research idea. L.B. and V.D. were responsible for the scientific literature review, visualization, research results interpretation, and conclusions preparation. M.Č. and Ž.K. were responsible for the research design, methodology, data collection and analysis, and validation of the research results. All authors have read and agreed to the published version of the manuscript.

Funding: This research received no external funding.

Institutional Review Board Statement: Not applicable.

Informed Consent Statement: Not applicable.

Data Availability Statement: Not applicable.

Conflicts of Interest: The authors declare no conflict of interest.

\section{References}

1. Amirtha, R.; Sivakumar, V.J.; Hwang, Y. Influence of Perceived Risk Dimensions on e-Shopping Behavioural Intention among Women-A Family Life Cycle Stage Perspective. J. Theor. Appl. Electron. Commer. Res. 2020, 16, 320-355. [CrossRef]

2. Ballestar, M.T. Editorial: Segmenting the future of e-commerce, one step at a time. J. Theor. Appl. Electr. Commer. Res. 2021, 16. [CrossRef]

3. Delgado-de Miguel, J.F.; Buil-Lopez Menchero, T.; Esteban-Navarro, M.Á.; García-Madurga, M.Á. Proximity Trade and Urban Sustainability: Small Retailers' Expectations Towards Local Online Marketplaces. Sustain. J. Rec. 2019, 11, 7199. [CrossRef]

4. Lin, Y.-C.; Lee, C.L.; Newell, G. The added-value role of industrial and logistics REITs in the Pacific Rim region. J. Prop. Investig. Finance 2020, 38, 597-616. [CrossRef]

5. He, B.; Bai, K.-J. Digital twin-based sustainable intelligent manufacturing: A review. Adv. Manuf. 2021, 9, 1-21. [CrossRef]

6. Pham, H.; Kim, S.-Y. The effects of sustainable practices and managers' leadership competences on sustainability performance of construction firms. Sustain. Prod. Consum. 2019, 20, 1-14. [CrossRef]

7. Oldenburg, R. The Great Good Place: Cafes, Coffee Shops, Community Centers, Beauty Parlors, General Stores, Bars, Hangouts and How They Get You through the Day, 1st ed.; Paragon House: New York, NY, USA, 1989.

8. Ritzer, G.; Ryan, J.M. (Eds.) The Concise Encyclopedia of Sociology; Blackwell Publishing Ltd.: Oxford, UK, 2011. 
9. Noble, A.J.; Schenk, T. Psychological distress after subarachnoid hemorrhage: Patient support groups can help us better detect it. J. Neurol. Sci. 2014, 343, 125-131. [CrossRef]

10. Phelan, H.A. A New Model for Shopping Malls I Intelligence I BoF. Available online: https:/ /www.businessoffashion.com/ articles/intelligence/a-new-model-for-shopping-malls (accessed on 28 September 2020).

11. Goldman, A.I. Pathways to Knowledge; Oxford University Press (OUP): Oxford, UK, 2002.

12. Guy, C.M. Classifications of retail stores and shopping centres: Some methodological issues. GeoJournal 1998, 45, 255-264. [CrossRef]

13. Guy, C. Internationalisation of large-format retailers and leisure providers in western Europe: Planning and property impacts. Int. J. Retail. Distrib. Manag. 2001, 29, 452-461. [CrossRef]

14. Nickson, D.; Warhurst, C.; Dutton, E. The importance of attitude and appearance in the service encounter in retail and hospitality. Manag. Serv. Qual. Int. J. 2005, 15, 195-208. [CrossRef]

15. Peiser, R.; Hamilton, D. Professional Real Estate Development: The ULI Guide to the Business, 3rd ed.; Urban Land Institute: Washington, DC, USA, 2012.

16. Burt, S.; Davies, K.; Dawson, J.; Sparks, L. Categorizing patterns and processes in retail grocery internationalisation. J. Retail. Consum. Serv. 2008, 15, 78-92. [CrossRef]

17. Blut, M.; Beatty, S.E.; Evanschitzky, H.; Brock, C. The Impact of Service Characteristics on the Switching Costs-Customer Loyalty Link. J. Retail. 2014, 90, 275-290. [CrossRef]

18. Sekliuckiene, J.; Žitkienè, R. Innovative Changes of the Retailing System's Competition Development in Lithuania. Manag. Organ. Syst. Res. 2003, 28, 125-135.

19. Rudienè, E.; Vengrauskas, V. Mažmeninès prekybos internacionalizavimo lygio rodikliu nustatymas ir ju vertinimas. Bus. Syst. Econ. 2011, 8234, 129-137.

20. Gudonavičienè, R.; Alijošienè, S. Influence of Shopping Centre Image Attributes on Customer Choices. Econ. Manag. 2013, 18, 545-552. [CrossRef]

21. Langvinienè, N.; Sekliuckiene, J. Internationalization in Retail Trade Services Market as Latecomer Countries Problem: The Case of Lithuania. Soc. Sci. 2011, 73, 74-85. [CrossRef]

22. ICSC. Shopping Center Definitions. Available online: https://www.icsc.com/news-and-views/research/shopping-centerdefinitions (accessed on 28 September 2020).

23. Thang, D.C.L.; Tan, B.L.B. Linking consumer perception to preference of retail stores: An empirical assessment of the multiattributes of store image. J. Retail. Consum. Serv. 2003, 10, 193-200. [CrossRef]

24. Cachero-Martinez, S.; Vazquez-Casielle, R. Living positive experiences in store: How it influences shopping experience value and satisfaction? J. Bus. Econ. Manag. 2017, 18, 537-553. [CrossRef]

25. Darian, J.C.; Tucci, L.A.; Wiman, A.R. Perceived salesperson service attributes and retail patronage intentions. Int. J. Retail. Distrib. Manag. 2001, 29, 205-213. [CrossRef]

26. Rao, F. Resilient Forms of Shopping Centers Amid the Rise of Online Retailing: Towards the Urban Experience. Sustain. J. Rec. 2019, 11, 3999. [CrossRef]

27. Han, H.; Sahito, N.; Nguyen, T.V.T.; Hwang, J.; Asif, M. Exploring the Features of Sustainable Urban Form and the Factors that Provoke Shoppers towards Shopping Malls. Sustain. J. Rec. 2019, 11, 4798. [CrossRef]

28. Barata-Salgueiro, T.; Guimarães, P. Public Policy for Sustainability and Retail Resilience in Lisbon City Center. Sustain. J. Rec. 2020, 12, 9433. [CrossRef]

29. Goodman, R. City Structures 22 Sustainable Form and the Shopping Mall City Structures 22-1. Sustainable Urban Form and the Shopping Mall: An Investigation of Retail Provision in New Housing Subdivisions in Melbourne's Growth Areas; Oxford University Press: Oxford, UK, 2003. [CrossRef]

30. Chebat, J.-C.; Michon, R.; Haj-Salem, N.; Oliveira, S. The effects of mall renovation on shopping values, satisfaction and spending behaviour. J. Retail. Consum. Serv. 2014, 21, 610-618. [CrossRef]

31. Pantano, E.; Timmermans, H. (Eds.) Advanced Technologies Management for Retailing; IGI Global: Hershey, PA, USA, 2011.

32. DeLisle, J.R. Toward the Global Classification of Shopping Centers. Int. Counc. Shopp. Centers En linea. 2009, 27. Available online: http//www.icsc.org/srch/rsrch/wp/GlobalRetailClass_Feb2009.pdf (accessed on 10 February 2009).

33. Coleman, P. Shopping Environments: Evolution, Planning and Design; Routledge: Oxford, UK, 2006.

34. Dunne, P.M.; Lusch, R.F.; Griffith, D.A. Retailing. South-Western College Pub, 4th ed.; South-Western College Pub: Mason, WA, USA, 2001.

35. Reilly, W.J. University of Texas Bulletin Methods for the Study of Retail; University of Texas: Austin, TX, USA, 1929.

36. Delic, M.; Knezevic., B. Development of Shopping Centers in Central and Southeastern Europe. In DAAAM International Scientific Book 2013; DAAAM International: Vienna, Austria, 2014; pp. 471-484.

37. Girdzijauskas, S.; Štreimikienè, D.; Mackevičius, R. Ekonominiu Svyravimu Logistinè Analizé Sektoriaus Stagnacija; Journal of Management: Klaipeda, Lithuania, 2009; Volume 14.

38. Perreault, W.D.; McCarthy, E.J. Basic Marketing: A Global-Managerial Approach, 15th ed.; McGraw-Hill/Irwin: Boston, MA, USA, 2005.

39. Varley, R.; Rafiq, M. Principles of Retail Management; Palgrave Macmillan: London, UK, 2004. 
40. Karatepe, O.M. Service Quality, Customer Satisfaction and Loyalty: The Moderating Role of Gender/Aptarnavimo Kokybè, Vartotoju Pasitenkinimas Ir Lojalumas Vartotoju Lyties Atžvilgiu. J. Bus. Econ. Manag. 2011, 12, 278-300. [CrossRef]

41. Blackwell, R.D.; Engel, F.J.; Miniard, P.W. Consumer Behavior; Harcourt College Publishers: London, UK, 2001.

42. Levy, M.; Witz, B.; Grewal, D. Retailing Management, 10th ed.; McGraw-Hill/Irwin: New York, NY, USA, 2019.

43. Sullivan, M.; Adcock, D. Retail Marketing; Cengage Learning EMEA: London, UK, 2002.

44. The SAGE. Handbook of Qualitative Research ISAGE Publications Inc. Available online: https://us.sagepub.com/en-us/nam/ the-sage-handbook-of-qualitative-research/book242504 (accessed on 23 February 2021).

45. Borowski, P.F. New Technologies and Innovative Solutions in the Development Strategies of Energy Enterprises. HighTech Innov. J. 2020, 1, 39-58. [CrossRef]

46. ICSC. The Socio-Economic Impact of European Retail Real Estate. Available online: https://www.icsc.com/uploads/t07subpage/European_Impact_Study-2017.pdf (accessed on 28 September 2017).

47. Zubrutè, L. Asociacijos Siūlo, Kaip Kompensuoti Patalpų Nuomos Kaštus-Verslo Žinios. Available online: https://www.vz. lt/nekilnojamasis-turtas-statyba/2020/04/10/asociacija-valstybei-siulo-kompensuoti-patalpu-nuomoskastus (accessed on 29 September 2020).

48. Čiulada, L. Didžiausi 2017 m. sandoriai ir ko laukti 2018-aisiais-Verslo žinios. Available online: https://www.vz.lt/rinkos/2018 /01/02/didziausi-2017-m-sandoriai-ir-ko-laukti-2018-aisiais\#ixzz6KbidaWfH (accessed on 28 September 2020). 